\title{
Event of harmattan dust transport in Kano State of Nigeria
}

\author{
D.C. Ochiegbu \\ Department of Environmental Resource Management, Abia state University Uturu \\ DOI: 10.29322/IJSRP.11.08.2021.p11628 \\ http://dx.doi.org/10.29322/IJSRP.11.08.2021.p11628
}

\begin{abstract}
The study was conducted at Kano state of Nigeria with data from the National Oceanic Atmospheric Administration (NOAA) using the meteorological station of Mallam Aminu international airport of Kano state. The wind direction of dust transport to Kano state indicated that the majority of the dust events blow from the North-east of Kano state Nigeria, which comes from Lake Chad that has aboundary with Nigeria. The back trajectory also confirmed that most of the dust to Kano comes from the North-east of Nigeria. The dust transportation and mobilisation to Kano state are easy due to the fine nature of the sediments. This harmattan dust mobilisation and deposition are naturally controlled especially by the meteorological factors completely away from the human influence. The effects of these winds are obviously felt in the homes, offices, schools, due to the widespread of the air-borne dust that covers beds, tables, chairs, cars and mostly all available surfaces.
\end{abstract}

Index Terms- Mineral dust, Dust transport, Emission, Trajectory, Visibility.

\section{INTRODUCTION}

$\mathrm{T}$ he desert areas serve as a source of atmospheric mineral dust, which helps to play a vital role in modulating climate through a number of complex processes. Globally, it is estimated that dust emission of 1100 to $5000 \mathrm{Tg}$ per year worldwide annually is emitted (Engelstaedter et al., 2006) although that estimations of individual studies varies strongly. Other model estimates that about $40-70 \%$ of the global dust emission occurs in North African deserts. The Sahara desert is the strongest dust source worldwide with the highest aridity next to the Chilean Peruvian desert. Mineral dust entrainment to the atmosphere is connected to the surface. The threshold problem of wind erosion and mobilization of soil particles shows that wind velocity and turbulent fluxes are necessary to mobilize soil particles. This erosion development depends strongly on surface conditions. Snow cover, vegetation and crusting inhibit particle mobilization. However, two major conditions have to be accomplished for dust emission; appropriate high wind velocities and soil surface conditions suitable for dust mobilization.

Both atmosphere dynamics and cloud formation processes are affected by dust aerosol (Hoose et al., 2010; Lohmann, 2005). It is clear that mineral dust is observed to transport over long distances. The strongest source area of dust, which is known to be the North Africa, provides largest contributions to the atmospheric dust content globally. The Atlantic Ocean is where the Saharan dust is been transported (Prospero \& Lamb, 2003; Prospero et al., 1996; Swap et al., 1992) moves towards the Mediterranean Sea (Stuut, 2009; Moulin et al., 1998) and east farther (Israelevich et al., 2002; Kubilay et al., 2005). Most of the times, dust is been transported towards Southern Europe (Lyamani et al., 2005; Rogora et al., 2004) and moves farther north towards North Europe and central (Coen et al., 2004; Ryall et al., 2002).

The mineral dust has a great impact in Kano state, Nigeria; about 183 people recorded the death in an air crash the year 1973 as a result of low visibility that is been caused by dust event (low visibility). The high rate of diseases caused by dust in Kano State such as catarrh, respiratory disorder and meningitis epidemics, and an increase in an auto car accident is great alarming due to low visibility, which causes loss of life in the city of Kano. The aim of this study is to investigate the source region and dust transport of mineral dust to Kano state.

1.2: Dust transport: The transport of dust movement depends on the height up to which the dust is mixed. The harmattan dust is mixed up into the atmosphere, which is transported within regional, local and large-scale circulation pattern. Dust particles are of different sizes; those larger than 60 $\mu \mathrm{m}$ in less than one day are removed from the atmosphere through dry deposition (Duce, 1995) in the absence of cloud and precipitation interactions. Larger dust particles sizes (60 - 2000 $\mu \mathrm{m})$ always fall out near the source area and at lower tropospheric levels particles are observed. The turbulent fluxes cause the small particles $(<60 \mu \mathrm{m})$ to mix over the entire boundary layer depth and stay up in the atmosphere for some days (Duce, 1995). When this occurs the dust aerosol is entrenched in the transport of the air mass. The mixing height and vertical extent of the dust layer are determined by the vertical turbulent fluxes. The local regimes are been impacted by surface conditions such as roughness and topography elements (e.g. stones, rocks, vegetation) moves the dusty air layers away from the source area.

Air masses properties cause the height of the dust layer to change during transport. This results in either subsidence or elevation, as well as determines if whether the dust layer is more likely to be impacted by local or large-scale circulation pattern conditions. In the upper tropospheric layers, the dust particles are mixed and can remain in the atmosphere for one to two weeks (Duce, 1995) and generally circulation regimes of the atmosphere will be influenced (Riemer et al., 2006; Mahowald et al., 2007).

The world's largest dust source the Sahara, which contributes the largest portion of the atmospheric dust content and displays seasonal fluctuating transport pattern with respect to pathway and amount. Transport directions are very important in 
the wind regimes, temperature and air mass characteristics like the moisture content are also important most especially for transport height. However, the dust export is affected by the seasonality of the dust source areas as it adjusts the temporal and local distribution of source areas and the dust flux discharging. The following mainly influences the tropical and subtropical North Atlantic towards Saharan dust export; a).Principal regional wind regimes, b).the activated dust sources areas of spatial distribution, c).the precipitable clouds that control atmospheric rainout and washout of dust and d).the boundary layer heights.

They boundary layers depth and that of the transport height of dust layers entering the tropical North Atlantic changes as a result of the seasons. Therefore, the seasons is a factor that depends on the transport path of Saharan dust layers towards the Atlantic, mainly related to the strength and direction of the trade winds and to the position of the inter-tropical convergence zone (ITCZ) (Engelstaedter et al., 2006; Mbourou et al., 1997; Moulin et al., 1997).It is assumed that the African Easterly Waves (AEW) is modulated by the variability of Saharan dust outbreaks towards the tropical Atlantic during northern hemispheric summer (Jones et al., 2004). The african easterly jet (AEJ) that is made up by the thermal gradient between the lower temperatures over the gulf of Guinea and high temperatures over the Sahara desert (Thorncroft \& Blackburn, 1999).

The Saharan Air Layer (SAL) are known be an enclosed Saharan dust layers propagating towards the North Atlantic (Dunion \& Velden, 2004) and it is expected to extend over a large area of the said North Atlantic far towards the west to the west indies (Carlson \& Prospero, 1972). The Saharan Air Layer (SAL) is located above the trade wind layer at a height of up to 5 to $7 \mathrm{~km}$ during hemispheric summer (Dunion \&Velden, 2004; Chiapello et al., 1997) while at the levels below 1.5 to $2 \mathrm{~km}$, the SAL is embedded in the trade wind layer during winter (Barkan et al., 2004; Chiapello et al., 1997). During the summer period, the Saharan dust air overlaps the moist, that is denser monsoon air, crosses the ocean and reaches the Atlantic embedded within the westwards winds as enclosed layer. The SAL extends downward into the marine boundary layer due to the sedimentation of dust particles when reaching the warm West Atlantic (Karyampudi et al., 1999). However, the middle-level easterly jet is capable of mixing dust from the SAL downwards which is been caused by deep moist convection strong enough to penetrate through the boundary layer inversion and strong vertical wind shears (Karyampudi et al., 1999).

Dust transport paths give information regarding areas where the dust can be expected to settle down, which is important for economical growth (ground transportation and aviation sector), government sector (restrictions on air quality), fertilization and health aspects. Dust particle surface may change concerning the chemical, optical and physical characteristics during atmospheric transport. The chemical (Photo) processes under aqueous or dry (e.g. in the presence of moist air or clouds) conditions together with reactions as result of adsorption of pollutants and soot (e.g. sulphur) occurs most times, this depends on the transport path in relation to emitted pollutants or clouds (e.g. aviation, biomass burning, shipping, industry) (Erel et al., 2006; Meskhidze et al., 2003). Particle-radiation interactions may change due to changing particle characteristics, the dust or the hygroscopic properties is been delivered by the bioavailability of micronutrients that is of very important for particle-cloud interactions (Fan et al., 2006; Johansen et al., 2000; Meskhidze et al., 2005).

1.3: Dust transport and harmattan Saharan dust towards Kano State, Nigeria: The largest source of mineral dust and dust plumes emanate from North Africa, which is the widest spread, dense and persistent. These dust are emitted from the desert regions and are transported into the atmosphere. These processes are highly variable in time and space with an annual peak during the summer season. The so-called Saharan air layer (SAL) that is uplifted dry and mineral dust particle-enriched air is transported over the West Africa and over the Atlantic; here it affects the cyclogenesis of tropical cyclones. The emission of dust over North Africa can occur due to the different weather systems;

- The upper-level troughs that penetrate to low latitudes (Knippertz and Fink, 2006).

The issue of high near-surface speeds that is caused by the downward mixing of momentum from nocturnal lowlevel jets. These may be due to the occurrence in relation to Saharan heat low dynamics (Knippertz, 2008) or with the lee of complex terrain that is generated in the lowlevel jets e.g. the Bodele region in the Northern Chad (Washington and Todd, 2006; Todd et al., 2008).

- The effect of density currents that results from the strong evaporation cooling along precipitating cloud bands across the northern part of Sahara (Knippertz and Fink, 2006) and in the southern Morocco along the Saharan side of the Atlas mountain chain (Knippertz et al., 2007).

- The leading edge of the Atlantic inflow caused by the density currents (Grams et al., 2010), which are related with dust uplift, was generated in model simulations Schwendike (2010).

- The mesoscale convective systems (MCSs) as a result of density currents are very efficient and effective for the emission of dust and its injection to altitudes, which favours the long-range transport. In the beginning of the monsoon season, this process is of very important, before the growing vegetation rapidly constrains local dust emission (Evanet al., 2007).

- The leading edge of the monsoon nocturnal flow in the inter-tropical discontinuity (ITD) region caused by highly turbulent winds that generate dust uplifting (Boukaram et al., 2008). Marsham et al., (2008) described that the thermodynamic characteristics of the dusty layer at the leading edge of the monsoon flow over the Sahel.

The presence of Saharan dust in the atmosphere causes visibility reduction that is a common characteristic in most parts of Kano state and sub-Saharan West Africa between the months of November and March known as the harmattan season every year. During the dry season which occurs during winter, the intertropical discontinuity (ITD) is displaced towards the south such that almost all parts of sub-Saharan West Africa between the Gulf of Guinea and Sahel are under the effect of the North-east trade winds which conveyances Saharan dust into most part of the regions of the world. 
The movement of dust entrainment and circulation from the source regions has shown a greater concern and research over the years (Engelstaedter et al., 2006; Todd et al., 2007). Brooks (2000) and Prospero et al., (2002) discussed the specific sources of dust within the Sahara and their most active periods. Different authors have estimated the annual dust output from these sources to range from 400 to $700 \mathrm{Tg} \mathrm{y}\urcorner$ (Schutz, 1980; d'Almeida, 1986; Swap et al., 1996). Chad basin as a whole and in particular the Bodele depression as suggested, contributes a large percentage of the dust load in the atmosphere globally (Prospero, 1999, 2002; Pinker et al., 2001; Goudie et al., 2009). It is identified that this region serve as a major source of dust conveyed across over Kano state of Nigeria towards the Gulf of Guinea in boreal winter season (Koren et al., 2006; Washington et al., 2003; Prospero et al., 2002; Middleton and Goudie, 2001; Israelevich et al., 2002; Kalu, 1979;).

The estimation made by Todd et al., (2007) calculated the total dust flux that is emitted from the Bodele to be $1.18 \pm 0.45 \mathrm{Tg}$ day $\urcorner^{7}$ wen there is a significant dust event. The result of increase in contribution to atmospheric dust load from the region is due to the shrinking of Lake Chad and the increasing desiccation of its basin due to the drought in Sahel over the past few decades (Middleton, 1985; Mbourou et al., 1997; Anuforom et al., 2007). As Anuforom et al., (2007) explained that the issue of the interannual variability of dust concentration found in the atmosphere over the Sahel region part of West Africa nearly follows arrangement of variability of rainfall and the altering areal magnitude of the Sahara.

Different trajectories at different times of the year are been followed by dust concentration from the Sahara. The trajectory of dust concentration during summer is highlighted Prospero et al., (1970, 1999), Prospero and Carlson (1970), and Prospero and Carlson (1972). D'Almeida (1986) accounted that the amount of mass of the dust produced in the Sahara and the neighboring region is transported towards the south to the Gulf of Guinea of about $60 \%, 28 \%$ is transported towards the west to the equatorial North Atlantic Ocean and about $12 \%$ towards the North to Europe. The highest mass, which is the southward transport that moves towards the Gulf of Guinea mainly, occurs during the northern hemisphere winter. Nigeria is found to lies along this trajectory; this causes the dust and sand storms not uncommon mostly in the northern part of Nigeria during this winter season known as dry (harmattan) season in Nigeria (Ologunorisa and Tamuno, 2003).

\section{METHOD}

2.1: Study site: Kano state is found to be one of the states located in Northern-western Nigeria that was created on May 27, 1967. The state is a closed-settled zone, having a population density of 2.66 persons per hectare and is borders Katsina state to the north-west, the south-east is Bauchi state, Jigawa state is located to the north-east while Kaduna state to the south-west as seen in (Fig: 1). Kano state is the largest city in the northern region part of Nigeria and the third largest in Nigeria after Lagos and Ibadan and in the Sahelian geographic region south of the Sahara. It has coordinates of $11.7574^{\circ} \mathrm{N}, 8.6601^{\circ} \mathrm{E}$. The 2006 census reported about 9 million people that make the state populous state in Nigeria. Kano metropolitan area covers $499 \mathrm{~km}^{2}$ and consists of eight local government areas as of the six mentioned above in addition to Ungogo and Kumbotso having a population of $2,828,861$ in 2006 Nigerian census as the metropolis is growing quickly. The climate region features savanna vegetation and a hot semi-arid zone. The annual average precipitation per year is about $690 \mathrm{~mm}$ (27.2 in), the bulk fall from June through September. The state of Kano is typically very hot throughout the year, though it is noticed to be cooler from December to February. During the months of December, January and February, night time temperatures are cool with average low temperatures of 11 to 15 ${ }^{\circ} \mathrm{C}\left(52\right.$ to $\left.59{ }^{\circ} \mathrm{F}\right)$.

2.2: Back trajectory of mineral dust to Kano state Nigeria: Back trajectories were created with the use of HYSPLIT for each day dust haze was present from 2011 to 2014 period. The back trajectories from 2011 - 2014 were examined and then grouped for statistical evaluation of dust transport patterns on days in which convective dust events, dust events, and when no dust events occurred. In this study, it compares trajectory contour plots for all days with at least one dust observation i.e. "high concentration" days.

They use of HYSPLIT model was reported by Draxler and Hess (1997), which support a wide range of simulations that is associated with the dispersion, long-range transport and deposition of pollutants. The back trajectories created with the data were gridded meteorological data from short-term forecasts from NOAA air resource Laboratory. A trajectory started from the receptor site (Mallam Aminu International Airport Kano state with coordinates $\left(12.0456{ }^{\circ} \mathrm{N}, 8.5221^{\circ} \mathrm{E}\right)$. The receptor site starts with the height of $500 \mathrm{~m}$ above ground level combined with the air parcel position that is referred to as an endpoint was calculated back in time for 72 hours. The days and time of dust events were input with the MET data that examine the days and time dust event outbreaks as both the Kano-in and Kano-out were input in the trajectory and was run, contours plots were displayed in the HYSPLIT trajectory endpoints. The HYSPLIT trajectory endpoints of the Kano out of all the days and time of dust events were inserted into ArcGIS map for remote sensing that displays the transport pathways of dust towards Kano state. 


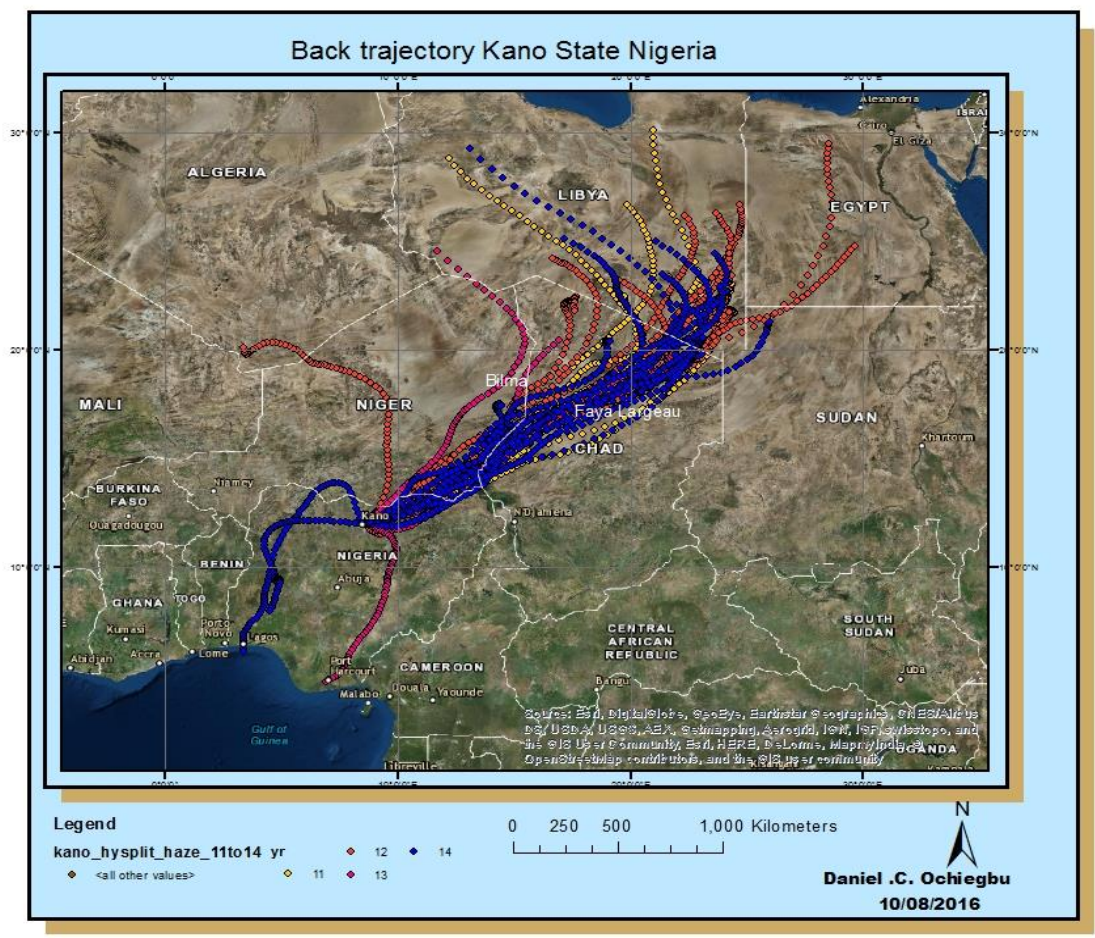

Fig 1: Back trajectory Kano state Nigeria (2011 - 2014).

2.3: Wind direction of Dust to Kano State: The wind direction of dust events in Kano state was presented in (Fig: 4.9) showing that the majority of the dust events blows from the Northeast of Kano state Nigeria which comes from Lake Chad that has aboundary with Nigeria. Majority of the dust comes falls between $45^{\circ}$ to $90^{\circ}$ (North-east) showing $75 \%$ which is the main wind direction of the dust to Kano state followed by $18 \%$ comes $0^{\circ}$ to $45^{\circ}$ (North-east) while about $4 \%$ comes from $90^{\circ}$ to $135^{\circ}$ (Southeast), about $2 \%$ falls within $315^{\circ}$ to $360^{\circ}$ (North-west) while the least of about $1 \%$ wind direction comes from $270^{\circ}$ to $315^{\circ}$ (Northwest).

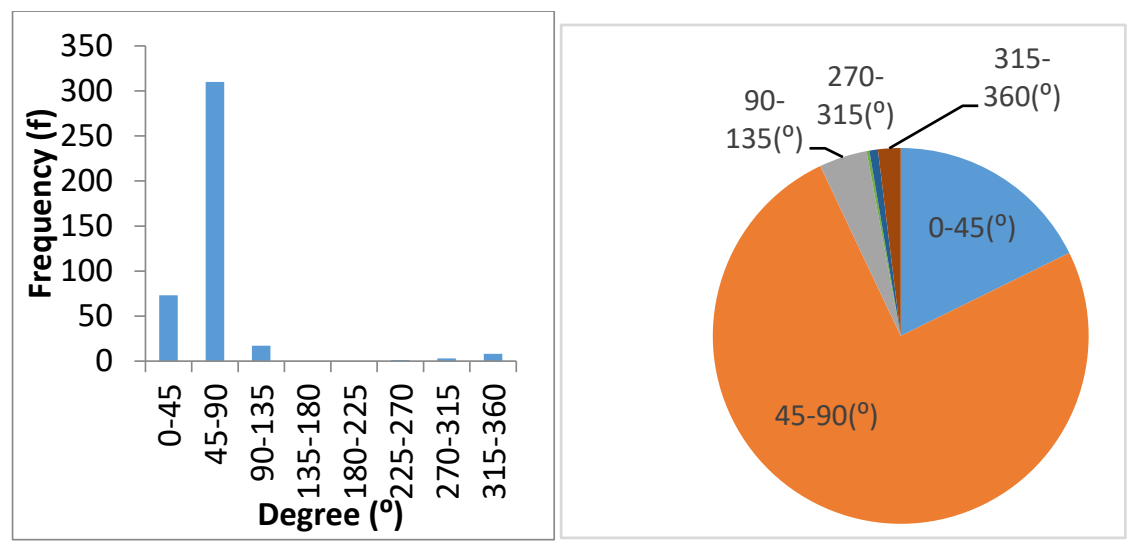

Fig 2: Wind frequency and direction (2000 - 2014)

3.1: Discussion: The wind direction of dust to Kano state was presented in (Fig: 2) about 93\% of the dust events to Kano state comes from the North-east of Nigeria while the few others come from the South-east and North-west. From the observation of the back trajectories carried out in (Fig: 1) it is believed that the Saharan dust that is affecting the Kano state of Nigeria during the Harmattan season comes originally from the alluvial plain of Bilma (Niger) and Faya Largeau (Chad) off the western slope of the Tibesti massif of North Africa. The plain of Bilma and Faya Largeau is without bias to any other source areas existing rather than the two for the Saharan dust in other parts of the Saharan desert.

The main interest here lies on the source and the meteorological factors that are favourable for emission, transport and deposition of the Saharan dust particles that affect the Kano state of Nigeria during the harmattan dust haze. There is a need to understand that Saharan dust also affects other parts of North Africa not only in West Africa during a different period of the year. For instance during summer in West Africa the dust is essentially absent south of the surface position of the Intertropical 
discontinuity, the trajectory of the Saharan dust moves or shifts to a westward direction which affect southern Algeria, Spanish Sahara, Morocco and more further West to reach to the Caribbean Islands across the Atlantic (Martin, 1975; Prospero, 1968).

Dust is usually raised at the source region whenever such synoptic features as described above are obvious on weather charts. This have been a useful forecasting tool in Nigeria for the development of the harmattan dust haze in West Africa from the Bilma - Faya Largeau source area (Fig 1). Therefore before there can be a reasonable and sustained discharge of a particulate substance into the atmosphere, the meteorological conditions must first be satisfied.The rise of the periodic development of strong surface wind is as a result of low-level anticyclogenesis with its associated pressure surge and instability that causes the periodic emission of dust into the atmosphere (Kalu, 1979). As the author confirmed that the velocity of 30 knots or more rely on observational evidence and this has been successfully used in Nigeria to predict the development of dusty atmosphere from the Bilma -Faya Largeau source area.

3.2: Recommendation: There is need to understand the characteristics of these dust transport and concentration in Kano state and to investigate more on mineral dust composition (mineralogical and chemical) and to study further on the soil moisture, wind speed velocity of dust in Kano state. Additionally, there is a need to study on human health impact on dust concentration and find an alternative measure to prevent or reduce dust events that are capable of impairing visibility and application of reforestation programme to curtail the amount of dust that is been transported to Kano state Nigeria. However, the study has also shown a little scale view that is insufficient to understand the highly complex nature of mineral dust redistribution but that the incorporation of both local, regional and global scale observations are required in order to understand fully the phenomena.

\section{REFERENCES}

[1] Barkan, J., Kutiel, H., \& Alpert, P. (2004). Climatology of dust sources in North Africa and the Arabian Peninsula, based on TOMS data. Indoor and Built Environment, 13(6), 407-419.

[2] Bou Karam, D., Flamant, C., Tulet, P., Todd, M. C., Pelon, J., \& Williams, E. (2009). Dry cyclogenesis and dust mobilization in the intertropical discontinuity of the West African Monsoon: A case study. Journal of Geophysical Research: Atmospheres, 114(D5).

[3] Brooks, N., \& Legrand, M. (2000). Dust variability over northern Africa and rainfall in the Sahel. In Linking climate change to land surface change (pp. 1-25). Springer, Dordrecht.

[4] Carlson, T. N., \& Prospero, J. M. (1972). The large-scale movement of Saharan air outbreaks over the northern equatorial Atlantic. Journal of applied meteorology, 11(2), 283-297.

[5] Chiapello, I., Bergametti, G., Chatenet, B., Bousquet, P., Dulac, F., \& Soares, E. S. (1997). Origins of African dust transported over the northeastern tropical Atlantic. Journal of Geophysical Research: Atmospheres, 102(D12), 13701-13709.

[6] Collaud Coen, M., Weingartner, E., Schaub, D., Hueglin, C., Corrigan, C., Henning, S., ... \& Baltensperger, U. (2004). Saharan dust events at the Jungfraujoch: detection by wavelength dependence of the single scattering albedo and first climatology analysis. Atmospheric Chemistry and Physics, 4(11/12), 2465-2480.

[7] d'Almeida, G. A. (1986). A model for Saharan dust transport. Journal of climate and applied meteorology, 25(7), 903-916.

[8] Draxler, R. R., \& Hess, G. D. (1997). Description of the HYSPLIT4 modeling system.

[9] Duce, R. A. (1995). Sources, distributions, and fluxes of mineral aerosols and their relationship to climate. Aerosol forcing of climate.
[10] Dunion, J. P., \& Velden, C. S. (2004). The impact of the Saharan air layer on Atlantic tropical cyclone activity. Bulletin of the American Meteorological Society, 85(3), 353-366.

[11] Engelstaedter, S., Tegen, I., \& Washington, R. (2006). North African dust emissions and transport. Earth-Science Reviews, 79(1-2), 73-100.

[12] Erel, Y., Dayan, U., Rabi, R., Rudich, Y., \& Stein, M. (2006). Trans boundary transport of pollutants by atmospheric mineral dust. Environmental science \& technology, 40(9), 2996-3005.

[13] Evan, A. T., Flamant, C., Fiedler, S., \& Doherty, O. (2014). An analysis of aeolian dust in climate models. Geophysical Research Letters, 41(16), 59966001.

[14] Fan, S. M., Moxim, W. J., \& Levy, H. (2006). Aeolian input of bioavailable iron to the ocean. Geophysical Research Letters, 33(7).

[15] Goudie, A. S. (2009). Dust storms: Recent developments. Journal of environmental management, 90(1), 89-94.

[16] Grams, C. M., Jones, S. C., Marsham, J. H., Parker, D. J., Haywood, J. M., \& Heuveline, V. (2010). The Atlantic inflow to the Saharan heat low: Observations and modelling. Quarterly Journal of the Royal Meteorological Society, 136(S1), 125-140.

[17] Hoose, C., Kristjánsson, J. E., Chen, J. P., \& Hazra, A. (2010). A classicaltheory-based parameterization of heterogeneous ice nucleation by mineral dust, soot, and biological particles in a global climate model. Journal of the Atmospheric Sciences, 67(8), 2483-2503.

[18] Israelevich, P. L., Levin, Z., Joseph, J. H., \& Ganor, E. (2002). Desert aerosol transport in the Mediterranean region as inferred from the TOMS aerosol index. Journal of Geophysical Research: Atmospheres, 107(D21), AAC-13.

[19] Johansen, A. M., Siefert, R. L., \& Hoffmann, M. R. (2000). Chemical composition of aerosols collected over the tropical North Atlantic Ocean. Journal of Geophysical Research: Atmospheres, 105(D12), 15277-15312.

[20] Jones, C., Mahowald, N., \& Luo, C. (2004). Observational evidence of African desert dust intensification of easterly waves. Geophysical research letters, 31(17).

[21] Kalu, A. E. (1979). The African dust plume: its characteristics and propagation across West Africa in winter. Scope, 14, 95-118.

[22] Karyampudi, V. M., Palm, S. P., Reagen, J. A., Fang, H., Grant, W. B., Hoff, R. M., ... \& Melfi, S. H. (1999). Validation of the Saharan dust plume conceptual model using lidar, Meteosat, and ECMWF data. Bulletin of the American Meteorological Society, 80(6), 1045-1076.

[23] Knippertz, P. (2008). Dust emissions in the West African heat trough-the role of the diurnal cycle and of extratropical disturbances. Meteorologische Zeitschrift, 17(5), 553-563.

[24] Knippertz, P., Deutscher, C., Kandler, K., Müller, T., Schulz, O., \& Schütz, L. (2007). Dust mobilization due to density currents in the Atlas region: Observations from the Saharan Mineral Dust Experiment 2006 field campaign. Journal of Geophysical Research: Atmospheres, 112(D21).

[25] Knippertz, P., \& Fink, A. H. (2006). Synoptic and dynamic aspects of an extreme springtime Saharan dust outbreak. Quarterly Journal of the Royal Meteorological Society: A journal of the atmospheric sciences, applied meteorology and physical oceanography, 132(617), 1153-1177.

[26] Koren, I., Kaufman, Y. J., Washington, R., Todd, M. C., Rudich, Y., Martins, J. V., \& Rosenfeld, D. (2006). The Bodélé depression: a single spot in the Sahara that provides most of the mineral dust to the Amazon forest. Environmental Research Letters, 1(1), 014005.

[27] Lyamani, H., Olmo, F. J., \& Alados-Arboledas, L. (2005). Saharan dust outbreak over southeastern Spain as detected by sun photometer. Atmospheric Environment, 39(38), 7276-7284.

[28] Lohmann, U., \& Feichter, J. (2005). Global indirect aerosol effects: a review. Atmospheric Chemistry and Physics, 5(3), 715-737.

[29] Mahowald, N. M. (2007). Anthropocene changes in desert area: Sensitivity to climate model predictions. Geophysical Research Letters, 34(18).

[30] Marsham, J. H., Parker, D. J., Grams, C. M., Johnson, B. T., Grey, W. M., \& Ross, A. N. (2008). Observations of mesoscale and boundary-layer scale circulations affecting dust transport and uplift over the Sahara. Atmospheric Chemistry and Physics, 8(23), 6979-6993.

[31] Mbourou, G. N. T., Bertrand, J. J., \& Nicholson, S. E. (1997). The diurnal and seasonal cycles of wind-borne dust over Africa north of the equator. Journal of Applied Meteorology, 36(7), 868-882. 
[32] Meskhidze, N., Chameides, W. L., Nenes, A., \& Chen, G. (2003). Iron mobilization in mineral dust: Can anthropogenic $\mathrm{SO} 2$ emissions affect ocean productivity?. Geophysical Research Letters, 30(21).

[33] Middleton, N. J., \& Goudie, A. S. (2001). Saharan dust: sources and trajectories. Transactions of the Institute of British Geographers, 26(2), 165181.

[34] Moulin, C., Lambert, C. E., Dulac, F., \& Dayan, U. (1997). Control of atmospheric export of dust from North Africa by the North Atlantic Oscillation. Nature, 387(6634), 691.

[35] Ologunorisa, T. E., \& Tamuno, T. T. T. (2003). Spatial and seasonal variations of sandstorms over Nigeria. Theoretical and applied climatology, 75(1-2), 55-63

[36] Pinker, R. T., Pandithurai, G., Holben, B. N., Dubovik, O., \& Aro, T. O. (2001). A dust outbreak episode in sub-Sahel West Africa. Journal of Geophysical Research: Atmospheres, 106(D19), 22923-22930.

[37] Prospero, J. M., \& Lamb, P. J. (2003). African droughts and dust transport to the Caribbean: Climate change implications. Science, 302(5647), 1024-1027.

[38] Prospero, J. M., Ginoux, P., Torres, O., Nicholson, S. E., \& Gill, T. E. (2002). Environmental characterization of global sources of atmospheric soil dust identified with the Nimbus 7 Total Ozone Mapping Spectrometer (TOMS) absorbing aerosol product. Reviews of geophysics, 40(1), 2-1

[39] Prospero, J. M. (1996). Saharan dust transport over the North Atlantic Ocean and Mediterranean: An overview. In The impact of desert dust across the Mediterranean (pp. 133-151). Springer, Dordrecht.

[40] Prospero, J. M., \& Carlson, T. N. (1972). Vertical and areal distribution of Saharan dust over the western equatorial North Atlantic Ocean. Journal of Geophysical Research, 77(27), 5255-5265.

[41] Prospero, J. M., \& Carlson, T. N. (1970). Radon-222 in the North Atlantic trade winds: Its relationship to dust transport from Africa. Science, 167(3920), 974-977.

[42] Riemer, N., Doherty, O. M., \& Hameed, S. (2006). On the variability of African dust transport across the Atlantic. Geophysical research letters, 33(13).

[43] Rogora, M., Mosello, R., \& Marchetto, A. (2004). Long-term trends in the chemistry of atmospheric deposition in Northwestern Italy: the role of increasing Saharan dust deposition. Tellus B: Chemical and Physical Meteorology, 56(5), 426-434.

[44] Ryall, D. B., Derwent, R. G., Manning, A. J., Redington, A. L., Corden, J., Millington, W., ... \& Fuller, G. W. (2002). The origin of high particulate concentrations over the United Kingdom, March 2000. Atmospheric Environment, 36(8), 1363-1378.
[45] Schütz, L. (1980). Long range transport of desert dust with special emphasis on the Sahara. Annals of the New York Academy of Sciences, 338(1), 515532 .

[46] Schwendike, J. (2010). Convection in an African Easterly Wave over West Africa and the eastern Atlantic: A model case study of Hurricane Helene (2006) and its interaction with the Saharan Air Layer (Doctoral dissertation, $\mathrm{PhD}$ thesis, Institut für Meteorologie und Klimaforschung, Karlsruher Institut für Technologie).

[47] Stuut, J. B., Smalley, I., \& O'Hara-Dhand, K. (2009). Aeolian dust in Europe: African sources and European deposits. Quaternary International, 198(1-2), 234-245.

[48] Swap, R., Ulanski, S., Cobbett, M., \& Garstang, M. (1996). Temporal and spatial characteristics of Saharan dust outbreaks. Journal of Geophysical Research: Atmospheres, 101(D2), 4205-4220.

[49] Swap, R., Garstang, M., Greco, S., Talbot, R., \& Kållberg, P. (1992). Saharan dust in the Amazon Basin. Tellus B, 44(2), 133-149.

[50] Thorncroft, C. D., \& Blackburn, M. (1999). Maintenance of the African easterly jet. Quarterly Journal of the Royal Meteorological Society, 125(555), 763-786.

[51] Todd, Martin C., D. Bou Karam, C. Cavazos, Christel Bouet, B. Heinold, J. M. Baldasano, Guy Cautenet et al. "Quantifying uncertainty in estimates of mineral dust flux: An intercomparison of model performance over the Bodélé Depression, northern Chad." Journal of Geophysical Research: Atmospheres 113, no. D24 (2008).

[52] Vrekoussis, M., Liakakou, E., Kocak, M., Kubilay, N., Oikonomou, K., Sciare, J., \& Mihalopoulos, N. (2005). Seasonal variability of optical properties of aerosols in the Eastern Mediterranean. Atmospheric Environment, 39(37), 7083-7094

[53] Washington, R., Todd, M. C., Engelstaedter, S., Mbainayel, S., \& Mitchell, F. (2006). Dust and the low-level circulation over the Bodélé Depression, Chad: Observations from BoDEx 2005. Journal of Geophysical Research: Atmospheres, 111(D3).

[54] Washington, R., Todd, M., Middleton, N. J., \& Goudie, A. S. (2003). Duststorm source areas determined by the total ozone monitoring spectrometer and surface observations. Annals of the Association of American Geographers, 93(2), 297-313

\section{AUTHORS}

First Author - D.C. Ochiegbu, Department of Environmental Resource Management, Abia state University Uturu. 